Historic, Archive Document

Do not assume content reflects current scientific knowledge, policies, or practices. 



\section{Wholesale Quotations}

$$
\text { From }
$$

\section{Lexington Seed Co.}

INCORPORATED

TELEPHONE

ASHLAND 468

(Connecting All Departments)

122, 124 Vine St.
Merits Your Confidence" $\frac{\text { Sec. } 4351 / 2, \text { P. L. \& R. }}{\text { U. S. POSTAGE }}$ PAID

LEXINGTON, KY.

Permit No. 44 
PRICES TO MERCHANTS ONLY

All Quotations on this sheet are Based on roday's Market F. O. B. Lexington, and Subject to change without notice. We will dhere to prices below as long as possible. QUOTATIONS ARE FOR FULL BAG ORDERS. LESS FULL BAG SHIPMENTS CHARGED SHADE HIGHER-Cotton Bags $40 \mathrm{c}$ Burlap $15 \mathrm{c}$ each. Bags not returnable.

TERMS NET CASH SUBJECT TO DE.

\section{INCORPORATED}

Field and Garden. Seed, Grain, Potatoes, Onion Setts, Feed, Fertilizers, In'secticidè:

Local and Long D stance Telephone 468

(Connecting All Departments)

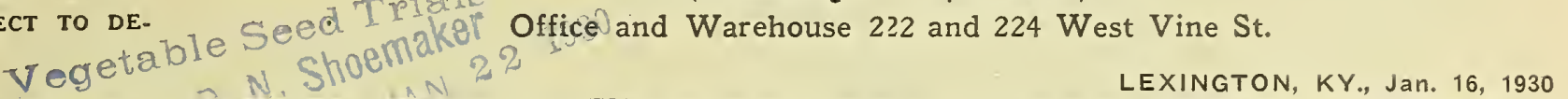
fhe Lexington Seed Company, Inć., gives no warranty, express or implied, as to description, quality, productiveness or any other matter of any seeds, grain, bulbs, it sells and will not be responsible for the crop.

FIELD SEEDS

$\begin{array}{lcr} & \text { RED CLOVER } \\ & \text { (Domestic) } & \\ \text { SELECT } & \text { Per bu. } & \text { Per cwt. } \\ \text { Export } & 12.60 & 21.00 \\ & 12.00 & 20.00 \\ \text { SELECT (Kentucky Grown) } & \\ & & 15.00\end{array}$

SELECT $\quad 25.00$

MAMMOTH CLOVER

SELECT $\quad 13.20-\quad \begin{array}{r}22.00 \\ 21.00\end{array}$

ALSIKE CLOVER

SELECT $\quad 12.60 \quad 21.00$

Export $-12.00 \quad 20.0 \%$

ALFALFA CLOVER
North Western 14.75
Export

SWEET CLOVER

White, hulled ......... 4.S0

Yellow, hulled _.... 5.40

\section{OTHER CLOVERS}

White Dutch _...-..-21.60

Lespadesa _.___ $\quad 3.75$

Korean _. $\quad 9.50$

Crimson

TINIOTHY

$\begin{array}{lr} & 3.38 \\ \text { SELECT } & 3.25 \\ \text { Export } & \text { BLUE GRASS }\end{array}$

SELECT _..... 2.94

Export $\quad 2.80$

1 lb. Cartol $31 \mathrm{c}$ each

10 Cartons $29 \mathrm{c}$ each LAWN MIXTURE

1 lb. Carton

$35 \mathrm{c}$ each

10 Cartons

$33 \mathrm{c}$ each

\section{SHADY LAWN MIXTURE For Dense Shade}

1. lb. Carton $50 \mathrm{c}$ each 10 Cartons

\section{REDTOP}

SELECT

Export

$\begin{array}{lc} & \text { ORCHARD GRASS } \\ \text { SELECT } & 2.45 \\ \text { Export } & 2.24\end{array}$

PASTURE MIXTURES

Properly proportioned for best results.

Clovers, Alsyke, Timothy Sweet Clover, per $100 \mathrm{lbs}$.

\section{PERMANENT PASTURE}

Blue Grass, Redtop, Orchard Grass, Per 100 lbs.

MILLET

(March Shipment) Per bu. Per cwt. Select Tenn. Cultivated 2.50

MISCELLANEOUS SEEDS

Dwarf Essex Rape

Canary Seed

Buckwheat

SOY BEANS

(March Shipment)

Manchu

Holly brook (southern

Mammoth (yellow)

\section{GRAIN}

SEED OATS

24.60 Northern White

Winter Turf

Early Burt

Feeding

9.00

Feeding corn

Cracked corn, $100 \mathrm{lbs}$

\section{SEED RYE}

(Recleaned)

Michigan Rosen

\section{ONION SETTS}

7.50 Yellow, 2 bu. bag for

Brown, 2 bu. bag for

Red, 2 bul. bag for

White, 2 bu. bag for

Less bag $10 \mathrm{c}$ bu. higher. Sack

extra on broken lots. Shipment last half February, 1930

\section{NORTHERN SEED POT ATOES}

The seed potato crop is reported as being very small.

Irish Cobblers Triumphs

Early Six Weeks

Per $21 / 2$ bu. bas

Early Ohios ....

15.50 Early Rose

White Elephant

Burbanks

\section{CANE SEED}

(For Fodder)

Redtop (recleaned)

Orange (recleaned)

Amber (recleaned)

\section{SEEDERS}

Horn, each

Cyclone, each $\$ 5.75$
5.95
5.95

3.30

3.25

1.70

\section{FERTILIZERS}

Large Tobacco Grower

Also fine for Gardens Per Ton

Per Bag, 125 lbs.

Grain Grower

12.00 Per, bag, 125 lbs.

Per Ton

Raw Bone Meal

Per bag, $125 \mathrm{lbs}$

Acid Phosphate

per b!1.

2.40
2.40

Fer Toli, 16 per cent-

NITRATE OF SODA

100 lb. sacks
Ton lots or more

\section{VIGORO}

Very fine for Lawn, Shrubbery and Flowers

$100 \mathrm{lb}$. bag for

1.40
80 $8 \mathrm{lb}$. bag for

$25 \mathrm{lb}$. bag for

LIME, CEMENT

1.35 Lime, per bbl. ...

\section{FEEDS}

MISCELLANEOUS

Mill Feed

Linseed Meal

Hog Tankage

Laying Mash

Meat Scraps
Charcoal Coarse or fine

POULTRY FEED

"Cock of the Walk"

No Grit or Shell

100 lbs.

$500 \mathrm{lbs}$

First Scratch $100 \mathrm{lbs}$.

For Baby Chieks $500.1 \mathrm{bs}$.

\section{GARDEN SEEDS}

\section{For February and March Shipm}

Prices in 1st Col. 10 to $15 \mathrm{lbs}$.

Prices in 2nd Col. $20 \mathrm{lbs}$. or more

(ats

ge, Dutch

.60

Carrots

Cucumbers, E. Fortune

Cucumbers, L. Green
Cucumbers, W. Spine

Kale, Siberian -.-

Lettuce, Simpson

Lettuce, Grand Rapid

Mustard

Okra

Parsnip

Peppers, sweet

.75 Peppers, hot

3.50
4.50

3.00

Pumplin, Ky: Field
Cabbage, Coppenhagen 3.00

GARDEN SEED (Continued)

Radish, any kind $\quad .50 \quad .45$

Striped Cushaw $\quad .70 \quad .65$

2.60 Squash, Wh. Bush ___ $\quad .60 \quad .55$

Squash, Yel, Bush _._. .65 .60

Salsify $\quad 1.50 \quad 1.45$

Spinach
2.00 $\quad .35$

2.00 Tomato, stone _-___-_._- $1.75 \quad 1.65$

Tomato, Ponderosa …_... $4.00 \quad 3.75$

Tomato, Bonnybest _...-2.75 2.50

Tomato, Marglobe $\quad 3.00 \quad 2.75$

Turnip, globe or flat $\quad .35 \quad .30$

Turnip, seventop _-_......

MUSHMELLON - CANTALOUPE

Tiptop

Rockyford ___

Heart of Gold _._. .65 .60

WATERMELON

Alabama Sweet

Ga. Rattlesnake

Halbert Honey

3.50 Irish Gray

2.00 Ice Cream

1.15 Kleckly Sweet

Sweet Heart

2.60 Stone Mountain

1.25 Watson Tom

BEANS (Dwarf)

Red Valentine

Burpee Stringless

cwt. Dwarf Horticultural

Giant Stringless

3.65 Marrowfat

4.50 Red Kidney

Tenn. Greenpod

BEANS (Pole)

Creaseback, Striped

Creaseback, White

Cut Short, Cornhill

Horti, Pole

$2.50 \mathrm{Ky}$. Wonder, brown

Ky. Wonder, white

Lazy Wife BEANS (Lima)

King of Garden, Pole

Large Pole

Burpee Bush

Fordhook Bush

Henderson Bush CORN

Adams Extra Early

1.40 Adams, Early

2.75 Bantam Golden

.55 Country Gentleman

60 Giant Golden

75 Stowell Evergreen

.65 Snow Flake

.5 Trucker's Favorite

$$
\text { PEAS }
$$

Alaska Dwarf

Claudit Tall

5 First and Best Dwar

35 Little Marvel Dwarf

5 Nott's Excelsior,Dwarf

2.85 Premium Gem Dwarf
ASK US FOR PRICES ON

LARGE LOTS
Sweet Peas, Spencer $\quad .80$

Nasturtium .60 


\section{Weight of Seeds to the Bushel}

and Amount Sown to the Acre

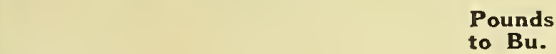

Alfalfa

Barley

Blue G...........................

Buckwheat .............50

Clover Alsike ...........60 60

Clover Crimson .........60

Clover, Medium ........60

Clover, Mammoth ........60

Sweet Clover, hulled .......60

White or Dutch Clover ....60

Japan Clover ............25

Cane, Broadcast .........50

Cane, in drills ..........50

Corn, Field ...........56

Corn, Ensilage .........56

Hemp ...............44

Millet, German .........50

Millet, Hungarian ... . . . . 48

Oats .................. 32

Orchard Grass ............14

Cow Peas ..............60 60

Canada Peas ............60

Red Top (Solid Seed) ..... . 14

Rape ................66 60

Rye ................56

Soy Beans ............60 60

Sudan Grass (in drills) .....50

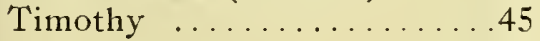

Vetch ...............60 60

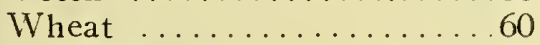

Pumpkin ............24

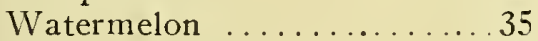

Kale ................54

Turnips .............56

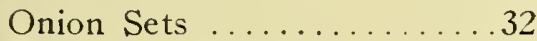

Potatoes (Irish) .........60

Potatoes (Sweet) ........52
Qty. Sown

15 Per Acre

70 to 100

20 to 30

25 to 30

6 to 8

12 to 15

8 to 10

8 to 10

15 to 20

6 to 10

10 to 12

40 to 50

6 to 8

8 to 10

50 to 60

40 to 50

50 to 75

35 to 50

64 to 80

20 to 30

90 to 120

90 to 120

10 to 12

5 to 6

84 to 112

90 to 120

12 to 15

10 to 15

40 to 60

60 to 75

2

3

3 to 4

$1 \frac{1 / 2}{2}$ to 2

Bu. to Acre

15 to 18

8 to 10

\section{Lexington Seed Company}

INCORPORATED

LEXINGTON, KY.

TELEPHONE

Ashland 468

(Connecting All Departments)

122-124 West Vine St. 
SOIL INOCULATION

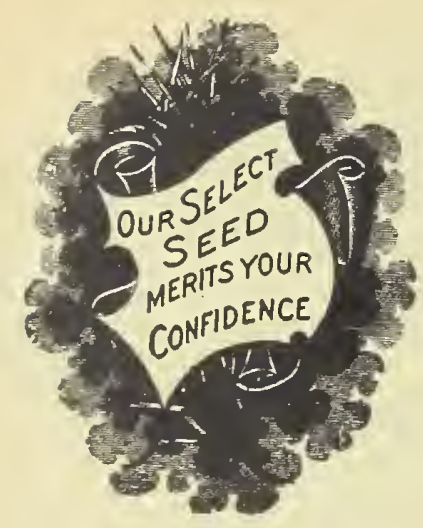

Soy Beans and Cow Peas:

For 10 bus.

For 5 bus.

For 2 bus.
1.75

1.05

.50
Alfalfa, Sweet and other Clover:

For 5 bus. - 3.35

For 1 bu.

For $1 / 2 \mathrm{bu}$. _ $\quad .45$

Please Name Kind Seed to be Inoculated.

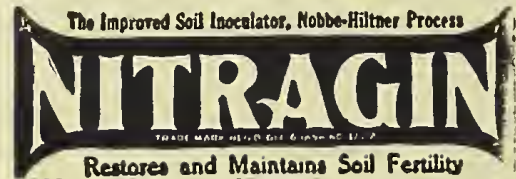

Our 37 Years Personal Experience in the Seed Business Should

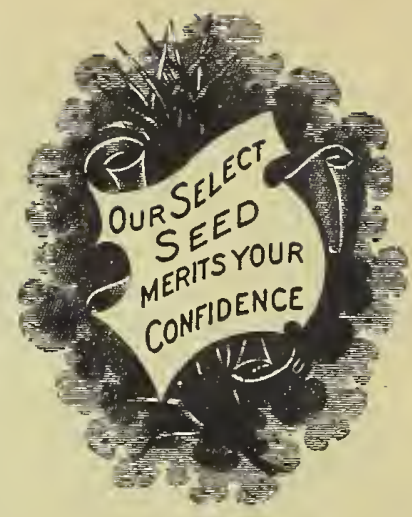
Prove an Advantage to You 